\title{
Fascia lata aortic valve reconstruction: long-term results in 33 patients
}

\author{
I. M. B RECKENR I D GE ${ }^{1}, M$. P. S IN G H, H. H. B E N T A L L, \\ and W. P. CLELAN D \\ Cardio-thoracic Unit, Hammersmith Hospital, London W.12
}

\begin{abstract}
Aortic valve reconstruction with autologous fascia lata was performed in 33 patients (mean age 35 years) in 1966 and 1967. Eighty-two per cent had cusp extension rather than replacement. while $33 \%$ required additional intracardiac procedures. There were seven hospital deaths $(21 \%)$ and 11 late deaths (33\%), a total mortality of $54 \%$ over four years. Six late deaths followed reoperation for recurrent incompetence, and two other patients survived reoperation. Endocarditis (rickettsial, fungal, and bacterial) occurred in five cases, all required reoperation for incompetence, and four died. Sixty-nine per cent of the survivors of operation left hospital with competent valves and did better than the $31 \%$ with leaking valves in terms of late deaths, endocarditis, and reoperation for incompetence. Of the 15 patients $(45 \%)$ still alive, 13 still have their original fascial valve, and of these only two (or perhaps three) have no diastolic murmur. Seven have insignificant murmurs and three have aortic incompetence. These poor results, particularly in the long term, make us sceptical about current enthusiasm for fascia lata heart valves.
\end{abstract}

Current enthusiasm for the use of autologous fascia lata for heart valve replacement is tempered by the short follow-up period for most of the reported cases (Ionescu and Ross, 1969 ; Ionescu, Ross, Deac, Grimshaw, Taylor, Whitaker, and Wooler, 1970a ; Ionescu, Ross, Deac, and Wooler, 1970b). The only series followed for a reasonably long time is that of Senning, the originator of the technique, who reported (1970b) 180 cases of aortic valve reconstruction with fascia lata since 1962.

In this paper we report our experience at Hammersmith Hospital, where 33 patients underwent aortic valve surgery using autologous fascia lata between January 1966 and November 1967, when dissatisfaction with the results led us to abandon the method. Adequate follow-up information is available on all but one of the survivors of operation over periods up to 60 months.

\section{CASE MATERIAL}

The 33 patients comprised 21 males and 12 females aged 8 to 54 (mean 35 ) years. There were 26 cases of aortic incompetence, one of stenosis, and six of both. Patients were selected for operation because of

'Present address: Hospital for Sick Children, Great Ormond Street. London W.C.1 dominant non-calcific aortic incompetence. Seventeen of the lesions were probably rheumatic in origin, six followed subacute bacterial endocarditis (S.B.E.), while the rest were the result of congenital abnormalities. In only four cases was there significant calcification of the valve. All patients were in cardiac grades II or III (New York Heart Association), except for four in grade I and one in grade IV.

In 11 patients $(33 \%)$ additional procedures were necessary. Three had mitral valve replacement (Hammersmith Mk. 3 prosthesis); three had closure of ventricular septal defects (together with closure of an atrial septal defect and excision of a subaortic diaphragm in one); two had extension of the posterior mitral cusp by a gusset of fascia lata (combined with annuloplasty in one and valvotomy in the other); while one underwent mitral and tricuspid valvotomy, and one excision of an ascending aortic aneurysm.

\section{OPERATIVE TECHNIQUES}

All operations were performed using a MelroseN.E.P. rotating disc oxygenator with moderate hypothermia $\left(28^{\circ}-30^{\circ} \mathrm{C}\right)$ and continuous coronary perfusion. At this time elective ventricular fibrillation was no longer employed, but femoral arterial cannulation was still routine.

Fascia lata was taken from a longitudinal incision in the left thigh, and the superficial surface was cleaned in situ. The fascia was kept until required 


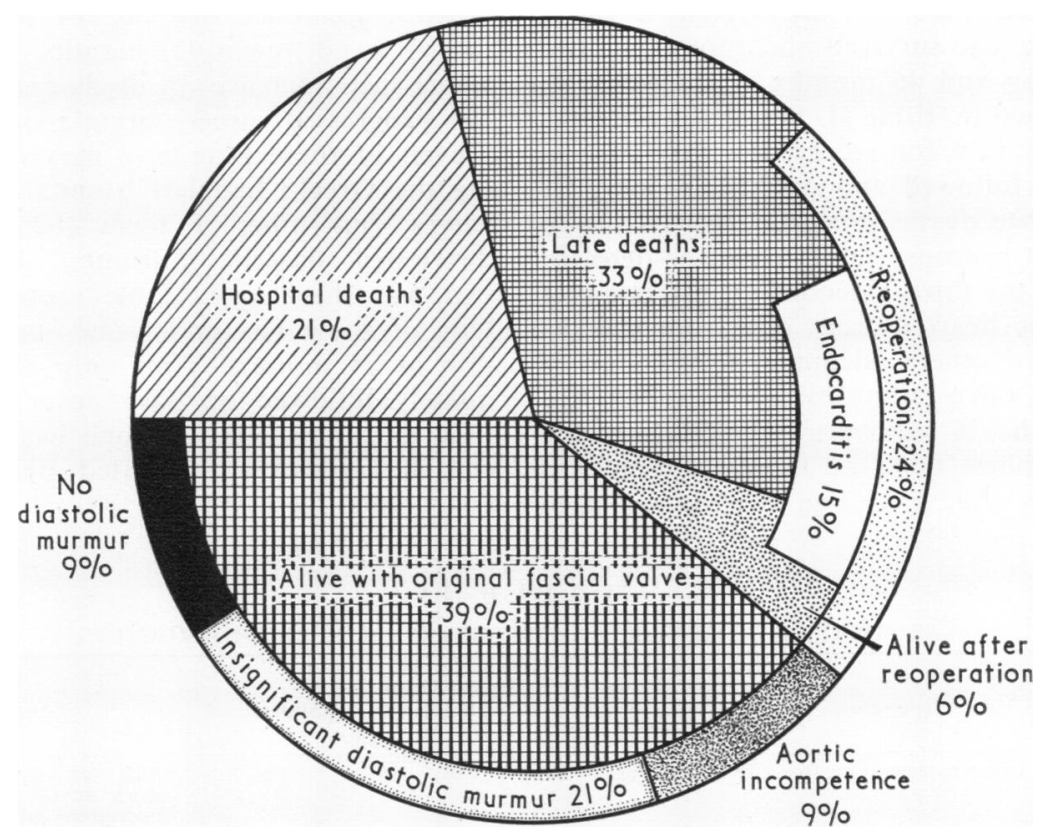

in heparinized saline and antibiotic solution (initially penicillin and streptomycin, later kanamycin and bacitracin), and was always inserted with its smoother deep surface towards the left ventricle. The thigh incision was closed at the end of the operation, usually without drainage. Haematoma formation and infection in these incisions were appreciable sources of postoperative morbidity.

In 22 cases the aortic valve cusps were left in situ and their free edges were extended by a single rectangular fascial strip. Extension of only one cusp was performed on four occasions. Five patients, including the only one with isolated stenosis, had excision and total replacement of the valve, and in an 18-yearold girl whose right coronary cusp had prolapsed through a ventricular septal defect, a single piece of fascia was used to close the defect and replace the excised cusp. In one case, two cusps were replaced and one was extended.

The techniques were based on those described by Senning (1967). Continuous sutures of 4-0 Mersilene were used to unite the fascia to cusp margins or the aortic annulus. Between the cusps the sutures were carried upwards for about $1 \mathrm{~cm}$ above the apex of the natural commissure and were brought out through the aortic wall to be tied over Teflon felt. Sometimes a single suture was placed to coapt the adjacent fascial margins at the commissures. For total replacement the fascial strip was wider, with a scalloped lower border to recreate the sinuses of Valsalva.
Postoperatively, penicillin and streptomycin were given for 10 days, and all patients after the first three received anticoagulants from the second day for four weeks.

\section{RESULTS (Figure)}

Seven of the 33 patients $(21 \%)$ died in hospital, three during operation, although in only two of the seven was failure of the fascial valve a contributory factor. Of the 26 who left hospital, 18 $(69 \%)$ had competent aortic valves on discharge, as judged by a normal blood pressure and the absence of a diastolic murmur. The difference in the clinical course between those 18 cases and the eight who left hospital with some leak is strikingly shown in Table $\mathbf{I}$.

T A B L E I

RESULTS IN RELATION TO AORTIC VALVE COMPETENCE AFTER OPERATION IN 26 SURVIVORS

\begin{tabular}{|c|c|c|c|c|}
\hline & & & Competent & Incompetent \\
\hline $\begin{array}{l}\text { No. of cases } \\
\text { Late deaths } \\
\text { Reoperation for } \\
\text { incompetence } \\
\text { Endocarditis .. } \\
\text { Still alive } \quad .\end{array}$ & $\begin{array}{l}\cdots \\
\cdots \\
\cdots \\
\cdots\end{array}$ & $\begin{array}{l}\cdots \\
\cdots \\
\cdots \\
\cdots\end{array}$ & $\begin{array}{l}18 \\
6(33 \%) \\
3(2 \text { deaths }) \\
2(11 \%) \\
12(67 \%)\end{array}$ & $\begin{array}{l}8 \\
5(62 \%) \\
5 \text { (4 deaths) } \\
3(37 \%) \\
3(37 \%)\end{array}$ \\
\hline
\end{tabular}

${ }^{1}$ Absence of diastolic murmur and normal blood pressure. 
Eleven late deaths $(33 \%$ of the original 33 cases, or $42 \%$ of those who survived operation) occurred between one day and 46 months after discharge. Details are shown in Table II. Six of these deaths followed reoperation for recurrent severe incompetence, which followed endocarditis in four. Of the five other late deaths, one was clearly due to valve failure (at necropsy fascia could be detected on only one of the three extended cusps), one was from ischaemic heart disease, one from suicide, and for the two others adequate information is lacking, so that valve failure cannot be excluded.

Thus 15 of the 26 survivors of operation were available for follow-up. One Greek patient was well six months after discharge but has not been heard from since, leaving 14 patients followed for 34 to 60 (mean 45) months. Three had some aortic incompetence on discharge, and in all this has progressed, necessitating reoperation in one. Eleven of these long-term survivors (not including the Greek) had left hospital with competent valves, but nine of them $(82 \%)$ subsequently developed diastolic murmurs, although in only two was there appreciable aortic incompetence. One of these has undergone successful reoperation at 24 months. Thus only two patients adequately followed up have never developed diastolic murmurs, although one has had a series of embolic episodes terminated by resuming anticoagulants.

T A B L E I I

LATE DEATHS AFTER FASCIA LATA AORTIC VALVE RECONSTRUCTION

\begin{tabular}{|c|c|c|c|c|c|c|}
\hline Age & Sex & Operation & $\begin{array}{c}\text { Valve } \\
\text { Competent } \\
\text { on Discharge }\end{array}$ & $\begin{array}{l}\text { Time of Death } \\
\text { after Discharge } \\
\text { (months) }\end{array}$ & Reoperation & Cause of Death \\
\hline 24 & $\mathbf{M}$ & 3 cusp extension for free $A I$ & Yes & 19 & Yes & $\begin{array}{l}\text { SBE (H. influenzae) after dental } \\
\text { work at } 12 \text { mth., caused AI. Re- } \\
\text { operation at } 19 \text { mth.-one com- } \\
\text { missure destroyed. S-E replacement; } \\
\text { died } 4 \text { days later. Necropsy- } \\
\text { cerebral haemorrhage }\end{array}$ \\
\hline 38 & $\mathbf{F}$ & $\begin{array}{l}\text { Single cusp perforation } \\
\text { (SBE). Covered by fascia. } \\
\text { H.H. mitral replacement } \\
\text { for ruptured chordae }\end{array}$ & Yes & 24 & No & $\begin{array}{l}\text { Died abroad. Valve known to be } \\
\text { incompetent. No other details; no } \\
\text { necropsy }\end{array}$ \\
\hline 41 & $\mathbf{M}$ & $\begin{array}{l}3 \text { cusp extension after inci- } \\
\text { sion and decalcification of } \\
2 \text { fused commissures }\end{array}$ & Yes & 6 & No & $\begin{array}{l}\text { Died of cardiac failure. No informa- } \\
\text { tion on valve competence. No } \\
\text { necropsy }\end{array}$ \\
\hline 46 & $F$ & 3 cusp extension for AI & Yes & 36 & No & $\begin{array}{l}\text { Well at } 24 \mathrm{mth} \text {. Probably suicide- } \\
\text { history of mental illness. No necropsy }\end{array}$ \\
\hline 30 & $\mathrm{~F}$ & $\begin{array}{l}\text { Previous SBE. Torn cusp } \\
\text { covered and extended by } \\
\text { fascia }\end{array}$ & No & 18 & Yes & $\begin{array}{l}\text { Endocarditis and emboli at } 12 \mathrm{mth} \text {. } \\
\text { Severe AI. Reoperation at } 18 \mathrm{mth} \text {. } \\
\text { fungal excrescence (aspergillus) on } \\
\text { fascia. Homograft replacement. Died } \\
\text { on table }\end{array}$ \\
\hline 24 & $\mathbf{M}$ & $\begin{array}{l}\text { AS/AI. R. and L. coronary } \\
\text { cusps replaced, non-coro- } \\
\text { nary cusp extended }\end{array}$ & No & 46 & Yes & $\begin{array}{l}\text { Endocarditis ( } R \text {. burneti) at } 6 \mathrm{mth} \text {. } \\
\text { Reoperation (1) at } 10 \mathrm{mth} \text {. De- } \\
\text { hiscence of fascia, aneurysm. S-E } \\
\text { replacement. Reoperation (2) at } \\
20 \text { mth. for further dehiscence due } \\
\text { to persistent endocarditis. Died at } \\
46 \text { mth.-staph. septicaemia. S-E } \\
\text { valve leaking. No necropsy }\end{array}$ \\
\hline 35 & $\mathbf{M}$ & $\begin{array}{l}3 \text { cusp extension for } \mathbf{A I} \text {. } \\
\mathbf{H . H} \text {. mitral replacement } \\
\text { for calcific } \mathbf{M S} / \mathbf{M I} \text {. }\end{array}$ & Yes & 21 & Yes & $\begin{array}{l}\text { Reoperation at } 8 \mathrm{mth} \text {. for recurrent } \\
\text { AI, MI. One aortic commissure } \\
\text { adjusted, perivalvular mitral leak } \\
\text { repaired. Still had AI, died from } \\
\text { cardiac failure }\end{array}$ \\
\hline 31 & $\mathbf{M}$ & $\begin{array}{l}3 \text { cusp extension. Subaortic } \\
\text { diaphragm excised, ASD } \\
\text { and VSD closed }\end{array}$ & No & 24 & Yes & $\begin{array}{l}\text { SBE at } 20 \text { mth. (diphtheroids), } \\
\text { severe AI. Reoperated, fascia des- } \\
\text { troyed. Homograft replacement. } \\
\text { Died } 18 \text { days later from ruptured } \\
\text { mycotic aneurysm of splenic artery } \\
\text { (necropsy) }\end{array}$ \\
\hline 45 & $\mathbf{F}$ & $\begin{array}{l}3 \text { cusp extension. Open } \\
\text { mitral and tricuspid valvo- }\end{array}$ & No & 3 & No & $\begin{array}{l}\text { Persistent TI with congestive failure. } \\
\text { Died. Necropsy-fascia had dis- } \\
\text { appeared from } 2 \text { of } 3 \text { cusps }\end{array}$ \\
\hline 44 & $\mathbf{F}$ & $\begin{array}{l}3 \text { cusp extension. } \mathbf{H} . \mathbf{H} \text {. } \\
\text { mitral replacement for } \mathbf{M I}\end{array}$ & No & 16 & Yes & $\begin{array}{l}\text { Cardiac arrest at } 16 \text { mth., resus- } \\
\text { citated. Reoperation-aortic valve } \\
\text { prolapsed. S-E prosthesis but died } \\
\text { on table. }\end{array}$ \\
\hline 35 & $\mathbf{M}$ & Single cusp extension & Yes & 1 day & No & $\begin{array}{l}\text { Sudden death at home day after dis- } \\
\text { charge in good condition. Necropsy } \\
\text { - valve competent, but huge left } \\
\text { ventricular and moderate coronary } \\
\text { atheroma }\end{array}$ \\
\hline
\end{tabular}

AI = aortic incompetence; $\mathbf{A S}=$ aortic stenosis; $\mathbf{A S D}=$ atrial septal defect; $\mathrm{VSD}=$ ventricular septal defect; $\mathbf{M I}=$ mitral incompetence; $\mathbf{M S}$

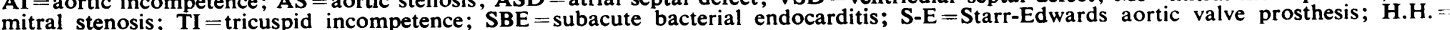
Hammersmith Mk. 3 mitral valve prosthesis 
The five patients who had excision and total replacement of the aortic valve by fascia lata did not fare any better than the 22 who had fascial extension of all their existing cusps. Two died in hospital (one from incompetence) while three have remained well, one with an insignificant diastolic murmur.

Five patients had fascial reconstruction of a single aortic valve cusp and did consistently badly, with one hospital death and three late deaths, one of which followed endocarditis-induced incompetence. The only survivor of this group has also required reoperation but still has some incompetence.

\section{DISCUSSION}

Advantages claimed for the use of fascia lata for cardiac valve replacement include its availability, freedom from thromboembolic complications, and prolonged survival after transplantation (Senning, 1967 ; Ionescu et al., 1970b). Nevertheless our experience with 33 patients who underwent aortic valve repair or replacement with fascia lata in 1966 and 1967 has not been encouraging. Seven deaths in hospital and 11 later constitute an overall mortality of $54 \%$, and only $69 \%$ of the survivors of operation left hospital with competent valves. These results are vastly inferior to those we obtained concurrently from the use of StarrEdwards prostheses and homografts and led us to discontinue the use of fascia lata.

Eight patients, or $31 \%$ of the survivors, required reoperation for progressive incompetence, and six subsequently died. Of these eight cases, three had competent valves on discharge while five did not. The development of postoperative incompetence has since become recognized as a more frequent complication of cusp extension than of total fascial replacement of the valve (Senning, 1967, $1970 \mathrm{a}, \mathrm{b}$; Bailey, 1970), and the majority (82\%) of our cases had extension procedures. Total replacement of the aortic valve seems to give better results than cusp extension (Senning, 1970a, b), but our five cases are too few to permit any conclusions. Our particularly bad results from singlecusp fascial reconstruction emphasize the inadvisability of such procedures by any method.

Another recognized problem has been the apparent liability of fascial valves to bloodstream infection by a variety of organisms, rickettsial and fungal as well as bacterial. In five of our patients
( $15 \%$ of the total, or $19 \%$ of those who survived operation) this complication occurred between 1 and 20 (mean 10) months postoperatively. Recurrent incompetence required reoperation in all of them, and four died subsequently, one from infection which persisted even after a third operation. Organisms found responsible were Rickettsia burneti, aspergillus, Haemophilus influenzae, diphtheroids, and Staphylococcus albus. Competence of the fascial valve did not preclude subsequent endocarditis, for of the five cases, two had apparently competent valves on discharge while three did not.

Whether the use of frame-mounted fascia, either in one piece (Ionescu et al., 1970a, b) or in segments (Edwards, Karp, Robillard, and Kerr, 1969), will give better long-term results than free grafting remains to be seen. Senning (1970a) reported 141 cases, about half of them total fascial replacement of the aortic valve, operated on between October 1962 and December 1968. There were 18 early and 19 late deaths, an overall mortality of $26 \%$. Endocarditis was responsible for seven of the late deaths. The results of our small five-year-old series are much less satisfactory, and on the basis of our unfortunate experience we urge caution in prematurely accepting fascia lata as the ideal valve substitute.

\section{REFERENCES}

Bailey, C. P. (1970). In Discussion of Ionescu, M. I., Ross, D. N., Deac, R. C., and Wooler, G. H. J. thorac. cardiovasc. Surg., 60, 352.

Edwards, W. S., Karp, R. B., Robillard, D., and Kerr, A. R. (1969). Mitral and aortic valve replacement with fascia lata on a frame. J. thorac. cardiovasc. Surg., $58,854$.

Ionescu, M. I., and Ross, D. N. (1969). Heart-valve replacement with autologous fascia lata. Lancet, 2, 335.

- Deac, R., Grimshaw, V. A., Taylor, S. H., Whitaker, W., and Wooler, G. H. (1970a). Autologous fascia lata for heart valve replacement. Thorax, 25, 46. replacement with autologous fascia lata. J. thorac. cardiovasc. Surg., 60, 331.

Senning, А. (1967). Fascia lata replacement of aortic valves. J. thorac. cardiovasc. Surg., 54, 465.

(1970a). In Proc. 1st International Workshop on Tissue Valves. Ann. Surg., 172, Suppl. to no. 1 (July), p. 18.

(1970b). In Discussion of Ionescu, M. I., Ross, D. N., Deac, R. C., and Wooler, G. H. J. thorac. cardiovasc. Surg., 60, 353. 